J. Perinat. Med. 15 (1987) 91

\section{Incidence of peri-intraventricular hemorrhage in premature neonates weighing more than $1500 \mathrm{~g}$}

\author{
Maurizio Amato, Henriette Howald, and Gaspar von Muralt
}

Department of Perinatal Medicine, Clinic of Obstetrics and Gynecology, University of Berne, Switzerland

\section{Introduction}

Peri-intraventricular hemorrhage (PIVH) is the most frequently encountered major neurologic disturbance in the Neonatal Intensive Care Unit (NICU) in preterm babies of less than 34 weeks of gestation or $1500 \mathrm{~g}$ of weight [7]. BuRNSTEIN et al. [6] found by CT screening an incidence of $50 \%$ PIVH of varying degree in patients of this age. At our department, in which premature neonates are routinely subjected to head ultrasonic scans in the first week of life, the high incidence of PIVH was confirmed demonstrating that $48.3 \%$ of all neonates weighing less than $1500 \mathrm{~g}$ had evidence of hemorrhage [3].

Because of reports of severe intracerebral bleeding also occurring in neonates weighing more than $1500 \mathrm{~g}$ at birth [5], a subgroup of prematures with a birthweight between $1501 \mathrm{~g}$ and $2500 \mathrm{~g}$ and gestational age greater than 34 weeks gestation was routinely screened by ultrasonographic scans in the first week of life. These results form the basis of this report.

\section{Patients and methods}

During an 18 month period all consecutively born neonates weighing between $1501 \mathrm{~g}$ and $2500 \mathrm{~g}$ at birth who were admitted to the Neonatal Intensive Care Unit or the intermediate care nursery were screened by cranial ultrasonography for evidence of PIVH. The ultrason-

\section{Curriculum vitae}

MaUrizio Amato was born in 1952. He studied medicine at the 2nd Department of Medical School of Naples (Italy) and qualified in 1976. He specialized in Pediatrics (Naples 1979) and Neonatology (Rome 1980) and has worked in the Departments of Pediatrics at the Universities of Naples and Berne (Switzerland). At present he is working in the field of Perinatal Medicine and Neonatal Intensive Care at theBerne University.

ographic scans were done on the first, third and seventh day of life. If one scan was abnormal, the neonate was studied weekly until the abnormality resolved or remained stable within the first month of life. Thereafter ultrasonic scans were obtained at intervals coincident with follow-up visits at 5 and 12 months of life.

Hemorrhages were graded according to the method of PAPILE et al. [9]: grade I represented germinal matrix hemorrhage; grade II was assigned to hemorrhages with blood within the lateral ventricular system but not distending it; grade III was assigned to hemorrhages filling and distending the ventricular system. Infants with parenchymal hemorrhages were defined as experiencing grade IV. 
Quantitative assessment of ventricular dilatation was obtained by measuring on sagittal scan the distance from the pulvinar to the posterior wall of the lateral ventricles near the origin of the occipital horn [3]. Mild dilatation was defined as a ventricular diameter of $0.25-0.5$ $\mathrm{cm}$, moderate dilatation as a ventricular diameter of $0.5-1.0 \mathrm{~cm}$, severe dilatation as a ventricular diameter greater than $1.5 \mathrm{~cm}$. The real-time scans were obtained through the anterior fontanelle using an ALOKA ECHO Scanner, Model SSD-256 with a $5.0 \mathrm{MHz}$ transducer for pediatrics. All examinations were recorded and hard copy was obtained with Polaroid photographs during the course of the examination.

Perinatal data included the major risk factors associated with the development of PIVH [11]: medications administered to the mother, duration of labor, intrauterine fetal distress, birth trauma, low Apgar Score, need of resuscitation or immediate ventilatory support. Data collected in the nursery included blood pressure determinations, blood gas monitoring, note of fluid infusions and transfusions including composition, volume and flow rate. Significant events including pneumothorax or patent ductus arteriosus were also noted.

Data were analyzed using the ordered chisquare test.

\section{Results}

During the 18 month interval, 75 consecutively life born neonates with a birthweight between $1501 \mathrm{~g}$ and $2500 \mathrm{~g}$ were studied. Mean gestational age, determined using the assessment score of BALLARD et al. [4], was $36 \pm 1.4$ weeks and mean birthweight $1890 \pm 310 \mathrm{~g}$. Five $(6.6 \%)$ of these neonates died and at postmortem examination they were found to have a PIVH. The other 70 neonates were serially managed: $16(21.3 \%)$ had abnormal scans with PIVH of varying degree. Comparing infants with and without PIVH, significant differences were noted with regard to low Apgar scores, need of resuscitation and/or artificial ventilation soon after birth. Six $(37.5 \%)$ of the 16 infants with PIVH suffered from birth asphyxia (Apgar score less than 4 at 1 minute and 6 at 5 minutes $)(P<0.005)$, and eight $(50 \%)$ needed resuscitation and/or ventilatory support after birth $(\mathrm{P}<0.002)$. Other adverse perinatal factors were not found to be directly correlated to the occurence of PIVH.

Table I delineates the grading of the hemorrhages and the grading of ventricular enlargement on follow-up sonograms of the survivors. The most common grade of the hemorrhages was moderate. Only two cases had a severe form (grade III and IV). One of the neonates developed progressive ventricular enlargement requiring shunting for hydrocephaly. The other ones had only transient ventricular dilatation at follow-up examination. All 16 survivors with PIVH returned for neurologic and developmental examination at 1 year of age. Follow-up assessment were normal in $11(68.7 \%)$ of them. Three $(18.7 \%)$ had only minor intellectual deficits and two $(12.5 \%)$ moderate to severe mental handicaps.

Table I. Ultrasonographic assessment of neurological complications in 70 preterm infants weighing more than $1500 \mathrm{~g}$.

\begin{tabular}{ll}
\hline & $\begin{array}{l}\text { Number of } \\
\text { patients }\end{array}$ \\
\hline Peri-intraventricular hemorrhage & $16 / 70(21.3 \%)$ \\
Grade I & $7(43.7 \%)$ \\
Grade II & $7(43.7 \%)$ \\
Grade III & $1(6.2 \%)$ \\
Grade IV & $1(6.2 \%)$ \\
Ventriculomegaly & $9 / 16(56.2 \%)$ \\
Grade I & $5(55.5 \%)$ \\
Grade II & $1(11.1 \%)$ \\
Grade III & $3(33.3 \%)$ \\
\hline
\end{tabular}

\section{Discussion}

In screening a population of consecutively born prematures with a birthweight greater than $1500 \mathrm{~g}$ by ultrasonography, $21.3 \%$ were found to have intracerebral bleeding [8]. Although this incidence is considerably below the one described for neonates weighing less than 
$1500 \mathrm{~g}$ [1], this study demonstrates that there is also a substantial risk of PIVH in larger prematures. In this group of neonates all grades of hemorrhages were represented. The overall mortality among neonates in this series with hemorrhages was $6.6 \%$ with the rate increasing with the severity of hemorrhage. By statistical analysis the degree of ventricular enlargement and the neurological outcome have been found, at follow-up examinations, to be well correlated to the extent of the cerebral-intraventricular hemorrhage $\left(\mathrm{X}^{2}\right.$-test, $\mathrm{P}<0.002$ and $\mathrm{P}<0.02$ respectively).

In the entire screened population only those neonates who had severe hemorrhages (grade III and IV) were clinically identifiable as having either suffered from severe birth asphyxia or required ventilation or both [11]. Autopsy studies of our patients who died with PIVH demonstrated that choroid plexus hemorrhage is the most common source of bleeding [10], probably the most common etiology being perinatal hypoxic-ischemic injury [12]. From our results it appears that routine-screening of all premature neonates with a birthweight $>1500 \mathrm{~g}$, as is the common practice for neonates weighing less than $1500 \mathrm{~g}$ at birth, is not necessary. It would seem reasonable to select for screening only those larger premature neonates who are severely ill, require resuscitation, ventilatory support or suffer birth asphyxia. The optimal time to screen such neonates in order to identify hemorrhage is the first week of life. Identification of persistant ventriculomegaly or resolution of ventricular dilatation can be followed by serial ultrasound controls [2].

Selective head ultrasonic screening reserved to high-risk infants is furthermore an adequate method to identify those neonates who need intervention or would benefit from follow-up examinations to optimize their neurologic outcome.

\section{Summary}

With the advent of modern methods of neonatal care, intracranial hemorrhage probably has become the most common neurological complication in premature infants weighing less than $1500 \mathrm{~g}$ at birth. This paper is a prospective study of 75 preterm infants of 34 weeks gestation or more and birth weight above $1500 \mathrm{~g}$ (range $1500 \mathrm{~g}$ to $2500 \mathrm{~g}$ ). All neonates were screened by cranial ultra-sonography for evidence of peri-intraventricular hemorrhage (PIVH). Perinatàl risk factors, incidence of

PIVH and neurological outcome were studied. Sonographic abnormalities were detected in $16(21.3 \%)$ of our patients. Intracranial hemorrhage was frequently associated with a low Apgar score, need of resuscitation and/or assisted ventilation immediatly after birth $(\mathrm{P}<$ 0.005). This study suggests, that ultrasound screening should be reserved to those large premature infants $(>$ $1500 \mathrm{~g}$ ) with high risk of hypoxic-ischemic injury.

Keywords: Peri-intraventricular hemorrhage, premature infants at risk, ultrasound.

\section{Zusammenfassung}

Inzidenz von peri-intraventrikulären Hirnblutungen bei Frühgeborenen mit einem Geburtsgewicht über $1500 \mathrm{~g}$ Seit den großen Fortschritten in der Neonatologie, scheint die intrakranielle Blutung die häufigste neurologische Komplikation bei Frühgeburten mit einem Geburtsgewicht unter $1500 \mathrm{~g}$ darzustellen. In dieser prospektiven Studie wurden 75 Frühgeborene mit Geburtsgewicht $>1500 \mathrm{~g}$ und 34 Gestationswochen mittels Schädel-Ultraschall auf das Vorliegen einer peri-intraventrikulären Blutung (PIVH) untersucht. Ebenso wurden die perinatalen Risikofaktoren, die Inzidenz der
PIVH und die neurologische Entwicklung untersucht. Bei 16 (21.3\%) unserer Patienten war die Sonographie abnorm. Intrakranielle Blutungen standen oft im $\mathrm{Zu}$ sammenhang mit niedrigem Apgar Score, der Notwendigkeit einer primären Reanimation und/oder künstlicher Beamtmung unmittelbar nach der Geburt $(\mathrm{P}<$ 0.05). Diese Studie weist darauf hin, daß bei größeren Frühgeborenen ( $>1500 \mathrm{~g}$ ) serielle Ultraschall-Untersuchungen auf diejenigen Fälle mit großem Risiko eines hypoxisch-ischämischen Schadens beschränkt sein sollten.

Schlüsselwörter: Peri-intraventrikuläre Blutung, Risiko-Frühgeborene, Ultraschall. 


\section{Résumé}

Incidence d'hémorrhagies peri-intraventriculaires chez les prématurés de poids de naissance au-dessus de $1500 \mathrm{~g}$ Dans la néonatologie moderne, l'hémorragie cérébrale est probablement la complication neurologique la plus fréquente. Dans cette étude prospective 75 prématurés avec poid de naissance $>1500 \mathrm{~g}$ et 34 semaines de gestation ont été analysés par sonographie du cerveau pour détecter la présence d'une hémorragie peri-intraventriculaire (PIVH). Les facteurs de risque perinatals,

l'incidence de la PIVH et le dévelopement neurologique ont été étudiés. La sonographie de $16(21.3 \%)$ de nos patients était anormale. L'hémorragie intracranienne était souvent associée à un Apgar score bas, la nécessité d'une réanimation et/ou ventilation artificielle immédiatement après la naissance $(P<0.05)$. Ce travail suggère que parmi les prématurés plus grands $(>1500 \mathrm{~g})$ le screening sonographique peut être réservé aux cas à grand risque d'une lésion hypoxique-ischémique.

Mots-clés: Hémorragie peri-intraventriculaires, prématuré à risque, ultrason.

\section{References}

[1] Amato M, H Howald, G von Muralt: Neurological prognosis of high-risk preterm infants with periintraventricular hemorrhage and ventricular dilatation. Eur Neurol 25 (1986) 241

[2] Аmato M, H Howald, G von Muralt: Ventrikulomegalie des Frühgeborenen. Pädiatr Prax 3 (1985) 611

[3] Amato M, H Howald, G von Muralt: Inzidenz der okzipitalen Ventrikulomegalie bei Frühgeborenen mit peri-intraventrikulärer Blutung. Ultraschall Med 5 (1985) 291

[4] Ballard J, K Kazmaier, M Driver: A simplified assessment of gestational age. Pediatr Res 11 (1977) 374

[5] Bergmann I, R Bauer, M Barmada, ET AL: Intracerebral hemorrhage in the full-term neonatal infant. Pediatrics 3 (1985) 488

[6] Burnstein J, L PAPILE, R BuRnstein: Intraventricular hemorrhage and hydrocephalus in premature newborns. A prospective study with CT. AJR 132 (1979) 631

[7] Fawer CL, A Calame, A ANDeregG: Real-time ultrasonography in the neonate: a systematic study of a high-risk infants population. Helv Paediatr Acta 39 (1984) 35
[8] McGuinnes A, W Smith: Head ultrasound screening in premature neonates weighing more than $1500 \mathrm{~g}$ at birth. Am J Dis Child 138 (1984) 817

[9] Papile LA, J Burnstein, H Kostler: Incidence and evolution of subependymal and intraventricular hemorrhages: a study of infants with birth weight less than 1500 g. J Pediatr 92 (1978) 529

[10] STANNARD MW, JF JimenZ: Ultrasound-autopsy correlation of the infant brain. Pediatr Res 15 (1981) 711

[11] Strauss A, D Kirz, H Modanlou, R Freeman: Perinatal events and intraventricular/subependymal hemorrhage in the very low-birth weight infant. Am J Obstet Gynecol 15 (1985) 1022

[12] VolPE J: Neonatal intracranial hemorrhage: pathophysiology, neuropathology and clinical features. Clin Perinatol 1 (1977) 77

Received July 19, 1985. Revised February 10, 1986. Accepted March 10, 1986.

Dr. Maurizio Amato Universitäts-Frauenklinik Schanzeneckstrasse 1 3012 Bern/Switzerland 